medical and surgical patients-there are no age or disease discriminations between the various types of somatic patients. Why should different criteria apply to different psychiatric conditions? The only consideration for admission surely is that the individual needs treatment.

A subnormal person over the age of 21 who is suffering from a disorder of a nature or degree which warrants his detention in hospital and for whom such care is essential in the interests of his own health or safety, or with a view to the protection of other persons, cannot be given hospital treatment if he cannot be persuaded to enter hospital voluntarily, unless he comes before a court or is transferred from prison or other penal institution by order of the Home Secretary.

Mindful that some of the over 21 age group will become deprived of the necessary parental support and will require special care, the Mental Health Act 1959 should be amended to the effect that in future all persons of any age suffering from mental subnormality who need to be admitted compulsorily into hospital should be dealt with on identical lines with those suffering from mental illness or severe mental subnormality under the present Act.-I am, etc.,

Rudolph PAyne

Little Plumstead Hospital,

Norwich, Norfolk

\section{Treatment of Pediculosis}

SIR,-For several years, we in this Authority have treated children and other members of their families infested with head lice with preparations containing D.D.T.-Suleo emulsion.

In 1967, it was decided to abandon the use of preparations containing D.D.T. because of possible harmful long-term effects of residual D.D.T. solutions. We then started using gamma benzene hexachloride (Lorexane), and this appeared to be very effective. However, in recent months, we are finding that this product is less effective, and feel that head lice are becoming resistant to it.

I would be glad to hear from others on this subject, and to find out if their experience with gamma benzene hexachloride is the same as ours and if they have found an effective alternative preparation for treating infestation by head lice.-I am, etc.,

Flintshire County Counci

G. W. ROBERTS

Mold, Flints

\section{Hypertonic Solutions to Induce Abortion}

SIR,-We read with interest the recent papers reporting the use of intra-amniotic urea (2 January, p. 28) and hypertonic saline (20 February, p. 434) to induce midtrimester therapeutic abortions.

We have found that although urea kills the fetus approximately $20 \%$ fail to abort spontaneously. Hypertonic saline also usually kills the fetus and it has recently been shown that there is a close correlation between the time of fetal death in utero and the initial concentration of salt in the liquor. ${ }^{1}$ However, as there is a failure rate following the use of both these agents and because occasional fatalities have been re-

ported following hypertonic saline, we have been interested in finding an additional substance which is both effective and yet free from side effects. One such hypertonic solution to be considered is mannitol, which if inadvertently given intravascularly is only likely to result in a diuresis.

The result of the instillation of $25 \%$ mannitol into the amniotic cavity in a small group of women is seen in the accompanying Table. In each instance liquor was drained off via a polyethylene cannula and then $200 \mathrm{ml} \mathrm{25 \%}$ mannitol instilled. No addi-

TABLE-Induction of Abortion by Intra-amniotic Mannitol

\begin{tabular}{|c|c|c|c|c|c|c|c|}
\hline Age & Parity & $\begin{array}{c}\text { Maturity } \\
\text { (weeks) }\end{array}$ & $\begin{array}{c}\text { Volume } \\
\text { of liquor } \\
\text { aspirated } \\
\text { (ml.) }\end{array}$ & $\begin{array}{c}\text { Volume } \\
\text { of } 25^{\circ} \\
\text { Mannitol } \\
\text { instilled } \\
\text { (ml.) } \\
\end{array}$ & $\begin{array}{l}\text { Outcome } \\
\text { (hours) }\end{array}$ & $\begin{array}{c}\text { Condition } \\
\text { of } \\
\text { fetus }\end{array}$ & Comments \\
\hline 20 & 0 & 20 & 200 & 200 & $\begin{array}{l}\text { Failed } \\
72\end{array}$ & - & $\begin{array}{l}\text { Aborted following hypertonic saline and } \\
\text { intravenous Syntocinon }\end{array}$ \\
\hline 19 & 0 & 18 & 180 & 200 & $\begin{array}{c}\text { Succeeded } \\
36^{1}\end{array}$ & Fresh & - \\
\hline 27 & 2 & 16 & 150 & 200 & $\begin{array}{l}\text { Failed } \\
96\end{array}$ & - & $\begin{array}{l}\text { Uterus larger. Aborted following urea and } \\
\text { artificial rupture of membranes }\end{array}$ \\
\hline 18 & 0 & 19 & 180 & 200 & $\begin{array}{c}\text { Failed } \\
120\end{array}$ & - & $\begin{array}{l}\text { Subsequent intravenous Syntocinon }(2 \\
\text { days) then artificial rupture of membranes. } \\
(400+\text { ml liquor })\end{array}$ \\
\hline 16 & 0 & 16 & 150 & 200 & $\begin{array}{l}\text { Succeeded } \\
52 !\end{array}$ & Fresh & - \\
\hline 21 & 0 & 16 & 160 & 200 & $\begin{array}{l}\text { Succeeded } \\
\quad 60\end{array}$ & Fresh & - \\
\hline 15 & 0 & 17 & 185 & 200 & $\begin{array}{c}\text { Succeeded } \\
30 !\end{array}$ & Fresh & - \\
\hline 23 & 0 & 15 & 150 & 200 & $\begin{array}{l}\text { Failed } \\
72\end{array}$ & - & $\begin{array}{l}210 \mathrm{ml} \text { liquor aspirated at subsequent intra- } \\
\text { amniotic urea. Failed to abort. Vaginal } \\
\text { evacuation. }\end{array}$ \\
\hline 23 & 1 & 16 & 145 & 200 & $\begin{array}{l}\text { Failed } \\
72\end{array}$ & - & Aborted following intravenous Syntocinon \\
\hline 36 & 0 & 16 & 150 & 200 & $\begin{array}{l}\text { Succeeded } \\
45 \frac{1}{4}\end{array}$ & Fresh & - \\
\hline 20 & 0 & 16 & 150 & 200 & $\begin{array}{l}\text { Succeeded } \\
\quad 42\end{array}$ & Fresh & - \\
\hline 20 & 1 & 18 & 175 & 200 & $\begin{array}{l}\text { Failed } \\
72\end{array}$ & - & $\begin{array}{l}390 \mathrm{mlliquor} \text { aspirated at subsequent success- } \\
\text { ful use of hypertonic saline }\end{array}$ \\
\hline
\end{tabular}

The mechanism whereby abortion occurs after the instillation of various substances into the amniotic cavity is not known for certain. It has been suggested that fetal death and suppression of placental endocrine function with a fall in progesterone production precedes the expulsive processes. However, it is unlikely that this is necessarily the case for the fetuses in this study were all fresh, and others have reported successful abortions with live fetuses. Similarly urea may fail even though the fetus may be macerated. It appears that a change in liquor volume is not important, tional measures were taken to encourage abortion for at least 72 hours. If no contractions were then present alternative measures were undertaken. Only $50 \%$ of patients aborted following this regimen and in each instance the fetus appeared fresh suggesting early fetal death is not a necessary prerequisite for abortion. Similarly, though we thought an increase in liquor volume would result and facilitate the process, several of those who failed had evidence of excessive accumulation of liquor three or more days following the procedure.
SIR,-The interesting paper of Dr. C. W. M. Whitty (2 January, p. 38) gave a penetrating account of some variants of migraine, including "cluster headache" or periodic migrainous neuralgia. This particular vascular pain syndrome of the head and face is in my opinion rightly classified as a variant of migraine, although it seems to be monophasic, exclusively vasodilatatory, and predominantly localized to the external carotid arterial system. ${ }^{1}$

The first description I have been able to trace is that of Marshall Hall, ${ }^{2}$ who named a similar syndrome "hemicrania intermittens" or "brow ague". Dr. Whitty's impression that for failure may occur when this is increased as with mannitol, or decreased, as is usually the case with urea. Until such time as there is more complete knowledge concerning abortion following this techniaue it is unlikely that an agent will be found which is invariably successful and without side effects.-We are, etc.,

I. L. CRAfT B. D. MUSA

Department of Obstetrics and Gynaecology, Kingston Hospital, Surrey

Kovacs, L., Resch, B., Szollosi, J., and Herczeg, J, Fournal of Obstetrics and Gynaecology of the British
Commonwealth, 1970, 77, 1132 . the syndrome is increasing in frequency may not be real, but could emerge from the fact that the diagnosis is made more frequently with increasing clinical awareness of the parcular symptoms.

In a period of one and a half years I saw 13 patients with the classical syndrome of periodic migrainous neuralgia and four patients with transitional symptoms to migraine, clinically linking the two syndromes together. ${ }^{1}$ In the three-year period 1967-70 I have observed further 26 patients with migrainous neuralgia. I want to draw attention to five of these patients presenting with chronic migrainous neuralgia. ${ }^{3}$ This parti- 
cular type was first mentioned by Symonds ${ }^{4}$ and later referred to by Rooke et al. ${ }^{5} \mathrm{Six}$ cases of chronic migrainous neuralgia were described by Earl and McArdle, ${ }^{6}$ and recently Ekbom ${ }^{7}$ pari passu has mentioned that five of his 105 patients with "cluster headache" had chronic symptoms.

The five patients observed by me were all men aged 24-53 years, average age 34 years. Following the definition of $\mathrm{Ekbom}^{7}$ three were classified as primary chronic with a duration of three-six years and two as secondary chronic with a duration of three and four years respectively. Three patients had a family history of classic migraine. The character and localization of the pain, the frequency and duration of the attacks, and the associated signs were typical of migrainous neuralgia, but the symptoms had a chronic course without remission for years in all cases. In three of the patients the pain could be alleviated by short-lasting physical exertion, in two by exposure to cold, and two patients got some relief by knocking their heads against the wall. Several patients had been subjected to futile operative procedures on the nose and teeth or on the sphenopalatine ganglion. In one patient the observation was made that the pain disappeared completely for a year following biopsy of the superficial temporal artery on the side of the pain and several years later for six months after the same procedure. In four patients some benefit from ergotamine was noted, but this was often transitory and insufficient.

The diagnosis of the secondary chronic cases of migrainous neuralgia should usually not meet with special difficulty as these patients have previously suffered from typical periodic migrainous neuralgia. In the primary chronic cases the diagnostic difficulties may be overcome by a careful clinical history revealing the typical short-lasting, frequent, always unilateral and ipsilateral attacks of pain and the local autonomic signs: ipsilateral conjunctival injection, epiphora, nasal congestion with stenosis and/or rhinorrhoea, and sometimes a partial Horner's syndrome. Ergotamine should always be tried in such cases and its effectiveness may be taken as an additional criterion of the correct diagnosis.

In chronic cases where ergotamines have some effect and are used more or less continuously for longer periods the danger of ergotism should always be considered. Chronic migrainous neuralgia may be more frequent than is generally recognized.-I am, etc.,

Bent de Fine Olivarius

University Department of Neurology,

Kommunehospitalet,

8000 Arhus C, Denmark

${ }^{1}$ Olivarius, B. de Fine, Manedsskrift for Praktisk Lagegerning, 1966, 44, 154.

, Marshall, Principles of the Theory and Practice of $\mathrm{Medic}$

${ }^{3}$ Olivarius, B. de Fine, Ammal Meeting of the Scandinavian Migraine Society, October 1970

4ymonds, C., Brain, 1956, 79, 217

Rooke, E. D., Rushton, J. G., and Peters, G. A. Proceedings of the Staff Meetings of the Mayn Clinic, 1962, 37, 433

'Earl, C. J., and McArdle, M. J., in Modern Neurology, ed. S. Locke, London, Churchill, 1969.

1970. K., Studies on Cluster Headache, Stockholm,

\section{Cytomegalovirus Meningo-encephalitis}

SIR,-We wish to draw attention to the fact that acquired cytomegalovirus infection in an adult may not be as mild as is commonly thought. Reported cases of aseptic meningo- encephalitis due to cytomegalovirus are few. ${ }^{1}$ - We wish to report a further case, the symptoms of the affected patient being prolonged and severe.

The patient, a 39-year-old male, an accountant, presented as an emergency to Cossham Memorial Hospital, Kingswood, Bristol, with a three-week history of increasing lethargy, anorexia, and objective vertigo. For three days prior to acimission he had severe, continuous frontal and occipital headache, with recurrent nausea and vomiting and mild photophobia. He had been pyrexial. There was no relevant past medical history. When examined he was noted to be very distressed from his headache; temperature $37 \cdot 4^{\circ} \mathrm{C}$. He had marked cervical and occipital lymphadenopathy, with an injected pharynx and definite neck stiffness, but Kernig's sign was negative. The remainder of the clinical examination was unremarkable apart from a sinus bradycardia of $56 /$ minute. A presumptive diagnosis of a virai meningoencephalitis was made and confirmed by lumbar puncture. C.S.F. pressure $140 \mathrm{~mm}$ protein $60 \mathrm{mg} / 100 \mathrm{ml}$, red cells $44 / \mathrm{mm}^{3}$, white cells $96 / \mathrm{mm}^{3}$ (85..., lymphocytes), sugar $70 \mathrm{mg} / 100 \mathrm{ml}$, culture no growth. The peripheral blood count and film were normal with a repeatedly negative Paul-Bunneil screening test for glandular fever.

Virological examination revealed the following.

\begin{tabular}{|c|c|c|}
\hline & $\begin{array}{l}\text { Seven Days } \\
\text { after } \\
\text { Admission }\end{array}$ & $\begin{array}{l}\text { Three Weeks } \\
\text { after } \\
\text { Admission }\end{array}$ \\
\hline $\begin{array}{l}\text { C.M.V. Complement } \\
\text { Fixation } \\
\text { (C.F.T.) on Serum. } \\
\text { Throat Swab Culture for }\end{array}$ & & \\
\hline 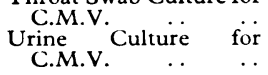 & $\begin{array}{l}\text { No growth } \\
\text { No growth }\end{array}$ & $\begin{array}{l}\text { No growth } \\
\text { No growth }\end{array}$ \\
\hline
\end{tabular}

The complement fixation antibody conversion to a significant titre must indicate a recent infection with cytomegalovirus, even though the virus was never isolated on the specimens taken. On further questioning we elicited the fact that the patient's 10-year-old daughter had had a mild upper respiratory tract infection approximately 10 days before the onset of the patient's symptoms. This would correspond with the known incubation period of cytomegalovirus infection. The remainder of his family, except his wife, subsequently developed a "cold-like" iilness, but virological screening of his family for cytomegalovirus infection produced no positive" results except a cytomegalovirus complement fixation titre of $1 / 128$ in the 10 -year-old daughter.

The patient required powerful analgesics to relieve his headache which lasted for a further three days after his admission. After that he was mobilized and discharged home, 12 days after admission, with no abnormal neurological signs being present. However, it was some three months before he filt fit cnough to resume his work, on a part-time basis only. He was still getting throbbing occipitai headache and had difficulty in conc.niration, but he had no other symptoms or signs.

We wish to make a plea that cytomegalovirus infection should be considered as a cause of aseptic meningitis, and that other complications of cytomegalovirus infection may occur-for example, myocarditis, hepatitis, and infective polyneuritis. These complications are rare but they may be responsible for similar conditions occurring in persons liable to cytomegalovrus-for example, those receiving fresh blood transfusions or immunosuppressive therapy, etc.-We are, etc.,

We wish to thank Dr. F. Page for permission to riport the above case.

\section{T. G. M. Perham}

E. O. Caul.

S. K. R. Clarke

A. G. F. Gibson

Cossham Memorial Hospital, Kingswood, Bristol,

' Klemola, E., W' eckman, N., Haltia, K., and Kaariainen, L., Acta Medica Scandinarica, 1907, 181, 603. Sterner, G., Agell, B. U., Wahren, B., and Espmark,
A., Scandinavian fournal of Infectious Diseases,

\section{Gynaecology in General Practice}

SIR,--In the interesting articles on gynaecology in general practice little has been said about the technique of clinical pelvic examination in the female. May I therefore briefly restate some of the elementary points which are not infrequently overlooked, perhaps with unfortunate consequences.

Vaginal examination should not start at the cervix nor exclude neighbouring organs. It should include inspection of the vulva, anus, and vaginal orifice, palpation of the vaginal wall and of the subjacent rectum and bladder, and palpation of the cervix (supplemented by speculum examination, with cytological and bacteriological examination when appropriate). Bimanual vagino-abdominal palpation of the uterus, tubes, ovaries, and adjacent organs (for example, sigmoid colon) should follow, the patient being in the dorsal position throughout.

Digital rectal examination in the female should be carried out with the patient in the dorsal position with the legs flexed and should include routine bimanual rectoabdominal examination of the uterus and ovaries-impracticable in the left lateral position with the uterus gravitating from the pelvis into the flank-whether or not the patient has gynaecological symptoms.-I am, etc.

Hexham, Northumberland

W. HUNTER

\section{Clinical Trials of Prostaglandins}

SIR,-I am directed by the Committee on Safety of Drugs to draw attention to the situation regarding the clinical trials of prostaglan ins in the United Kingdom.

At the present time prostaglandin preparations of $E_{2}$ and $F_{2}$ fractions manufactured by the Upjohn Company have received clinical trial clearance from the Committee. However, the Committee is concerned that there is growing clinical use of other preparations of these fractions as well as other prostaglandin fractions which have not been submitted to them for assessment.

Individual clinicians, of course, have the rigit to exercise their own responsibility and to use whatever materials they feel are most appropriate to the treatment of each patient. While the Commitiee is anxious that there sicould not be any interruption of potentiaily inportant clinical research programmes they wish to emphasize that they can offer no advice on the safety or quality of a product unless a full submission relating to the detailed scientific work conducted with that product has been presented to them by nanutacturers for assessment.-I am, etc., Medical Assessor,
Committee on Safety of Drugs 